\title{
PERAMALAN JUMLAH PENUMPANG KERETA API DI INDONESIA MENGGUNAKAN METODE EKSPONENTIAL SMOOTING
}

\author{
Affiati Oktaviarina \\ Jurusan Matematika, Fakultas Matematika dan Ilmu Pengetahuan, Universitas Negeri Surabaya \\ affiatioktaviarina@unesa.ac.id
}

\begin{abstract}
Abstrak
Kereta api merupakan salah satu jenis transportasi umum yang banyak diminati karena mempunyai banyak kelebihan antara lain harga tiket yang bervariasi dan relatif terjangkau oleh seluruh lapisan masyarakat banyak pilihan stasiun tujuan, jadwal keberangkatan dan jenis kelas gerbong yang tersedia. Pertumbuhan jumlah penumpang kereta api di Indonesia tahun 2006 sampai dengan 2017 merupakan data time series yang menunjukkan tren naik dari tahun ke tahun. Double Eksponential Smoothing merupakan metode Eksponensial Smoothing terbaik untuk meramalkan data jumlah penumpang kereta api karena memliliki nilai SSE, MSE dan MAPE terkecil yaitu 71.686.012, 3.258.455,1 dan 0,05. Model Double Eksponensisal yang dihasilkan adalah $S_{t}=0,645 x_{t}+0,355\left(S_{t-1}+b_{t-1}\right)$ dan $b_{t}=0,154\left(S_{t}+S_{t-1}\right)+0,846 b_{t-1}$ dan $b_{t}=0,14\left(S_{t}-S_{t-1}\right)+0,86 b_{t-1}$. Hasil peramalan jumlah penumpang kereta api bulan Januari sampai dengan Desember 2018 menunjukkan adanya pertumbuhan dari bulan ke bulan sepanjang tahun.
\end{abstract}

Kata Kunci: eksponensial smoothing, double eksponential smoothing, MSE, SSE, MAPE

\section{PENDAHULUAN}

Kereta api merupakan salah satu jenis transportasi umum yang banyak diminati karena mempunyai banyak kelebihan antara lain harga tiket yang bervariasi dan relatif terjangkau oleh seluruh lapisan masyarakat banyak pilihan stasiun tujuan, jadwal keberangkatan dan jenis kelas gerbong yang tersedia. Sejarah ndustri kereta api di Indonesia dirintis oleh Belanda pada 1864 dengan nama NV Nederland Indische Spoorweg Mastshappij yang merupakan cikal bakal PT. Kereta Api Indonesia, pada masa penjajahan Jepang diganti nama menjadi Tedsudo Kyoku (Semuel \& Wijaya, 2010).

Eksponensial smoothing merupakan suatu metode yang cukup akurat untuk meramalkan data time series (Ferbar Tratar, Mojškerc, \& Toman, 2016). Penelitian terkait peramalan time series menggunakan Eksponential smoothing telah banyak dilakukan antara lain Bermudez menghasilkan rumus untuk metode peramalan HolWinters dengan menyederhanakan estimasi Maksimum Likelihood, parameter smoothing dan nilai awal (Bermúdez, Segura, \& Vercher, 2007) sedangkan Aimran menyimpulkan bahwa metode Holt-Winters merupakan metode terbaik unutk meramalkan data jumlah populasi penduduk Malaysia (Aimran \& Afthanorhan, 2014).

\section{METODE}

Data yang digunakan dalam penelitian ini adalah data jumlah penumpang kereta api di Indonesia Januari 2006 sampai dengan Oktober 2017 yang diperoleh dari www.bps.go.id. Data Januari 2006 sampai dengan Desember 2015 digunakan sebagai data training, data Januari 2016 sampai dengan Oktober 2017 digunakan sebagai data testing. Tahapan yang dilakukan dalam penelitian ini adalah melakukan statistika deskriptive, plot data untuk mengetahui tren, mengestimasi nilai parameter $\alpha$ metode Single Eksponential Smoothing, mengestimasi nilai parameter $\alpha$ dan $\beta$ metode Double Eksponential Smoothing, mengestimasi nilai parameter $\alpha$, $\beta$ dan $\gamma$ metode Triple Eksponential Smoothing, melakukan pemilihan metode terbaik dengan membandingkan tingkat keakuratan peramalan data training, yang terakhir melakukan peramalan data jumlah penumpang kereta api tahun 2018 menggunakan metode terbaik.

\section{HASIL DAN PEMBAHASAN}

\section{Statistika Deskripsi}

Statistika deskriptive dari data training adalah sebagai berikut data terkecil adalah 10969, data terbesar adalah 29831, dengan rata-rata jumlah penumpang selama 10 tahun adalah 17968 .

Plot data jumlah penumpang kereta api Januari 2006 sampai dengan Desember 2015 menunjukkan data tidak stasioner dan terdapat tren naik, seperti terlihat pada gambar 1 di bawah ini. 
Affiati Oktaviarina: Peramalan Jumlah Penumpang Kereta Api di Indonesia Menggunakan Metode Eksponential Smoothing

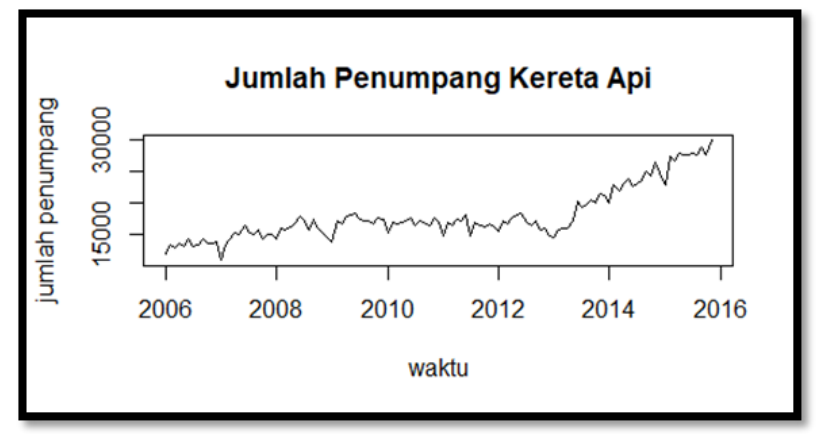

Gambar 1. Plot Jumlah Penumpang Kereta Api

\section{Single Eksponential Smoothing}

Estimasi parameter Metode Eksponential Smoothing disajikan pada tabel di bawah ini.

Tabel 1. Estimasi Parameter Metode Single Eksponential Smoothing

\begin{tabular}{ccccc}
\hline \multicolumn{3}{c}{ Estimasi Parameter Single Eksponential Smooting } & $\boldsymbol{\gamma}$ \\
$\boldsymbol{\alpha}$ & $\boldsymbol{\beta}$ & - & SSE \\
0,595 & - & - & 151.160 .869 \\
0,605 & - & - & 151.091 .398 \\
0,614 & - & - & 150.931 .160 \\
0,623 & - & - & 15.107 .756 \\
0,637 & - & 151.165 .353 \\
\hline \hline
\end{tabular}

Dari Tabel 1 diperoleh nilai $\alpha=0,614$ yang mempunyai SSE terkecil sebesar 150.931.160, dengan bentuk

$$
S_{t}=0,614 y_{t-1}+0,38 S_{t-1}
$$

persamaan Single Eksponential Smoothing adalah sebagai berikut

di mana $S_{\mathrm{t}}$ adalah nilai peramalan smoothing pada periode $\mathrm{t}$.

\section{Double Eksponential Smooting}

Nilai estimasi parameter $\alpha, \beta$ dan $\gamma$ dari Metode Double

Ekponential Smoothing adalah sebagai berikut:

Tabel 2. Estimasi Parameter Metode Double Eksponential Smoothing

\begin{tabular}{cccc}
\hline \multicolumn{2}{c}{ Estimasi Parameter Single Eksponential Smooting } & $\boldsymbol{\gamma}$ \\
0,639 & $\boldsymbol{\beta}$ & - & 169.346 .010 \\
0,645 & 0,144 & - & 157.444 .122 \\
0,153 & 0,154 & - & 239.411 .890 \\
0,675 & 0,536 & - & 166.903 .520 \\
0,357 & 0,234 & - & 198.435 .334 \\
\hline \hline
\end{tabular}

Kombinasi nilai $\alpha=0,645 ; \beta=0,154 ; \gamma=-$, memberikan nil ai SSE terkecil diantara yang lainnya sebesar 157.444.12,
Model persamaan Double Eksponential Smoothing adalah sebagai berikut:

$$
\begin{aligned}
& S_{t}=0,645 X_{t}+0,355\left(S_{t-1}+b_{t-1}\right) \\
& b_{t}=0,154\left(S_{t}+S_{t-1}\right)+0,846 b_{t-1}
\end{aligned}
$$




\section{Triple Eksponential Smooting}

Parameter diestimasi dengan beberapa nilai sebagai berikut

Tabel 3. Estimasi Parameter Triple Eksponential Smoothing

\begin{tabular}{|c|c|c|c|}
\hline \multicolumn{3}{|c|}{ Estimasi Parameter Single Eksponential Smooting } & \multirow[b]{2}{*}{ SSE } \\
\hline $\boldsymbol{\alpha}$ & $\beta$ & $\gamma$ & \\
\hline 0,569 & 0,051 & 0,528 & 78.337 .846 \\
\hline 0,653 & 0,325 & 0,254 & 99.605 .608 \\
\hline 0,365 & 0,732 & 0,751 & 180.443 .100 \\
\hline 0,823 & 0,437 & 0,534 & 122.433 .510 \\
\hline 0,569 & 0,835 & 0,939 & 175.994 .255 \\
\hline
\end{tabular}

Nilai SSE $=78.337 .846$ adalah nilai terkecil dengan $\alpha=0,569 ; \beta=0,051 ; \gamma=0,528$ dan persamaan Triple

Eksponential Smoothing mempunyai bentuk seperti dibawah ini

$$
\begin{aligned}
& S_{t}=0,569\left(X_{t}-I_{t-1}\right)+0,431\left(S_{t-1}+T_{t-1}\right) \\
& T_{t}=0,051\left(S_{t}-S_{t-1}\right)+0,949 T_{t-1} \\
& l_{t}=0,528\left(X_{t}-S_{t}\right)+0,472 I_{t-1}
\end{aligned}
$$

\section{Pemilihan Metode Terbaik}

Pada bagian ini akan dilakukan pemilihan metode terbaik dengan membandingkan tingkat keakuratan peramalan data testing, metode dengan nilai SSE, MSE dan MAPE terkecil merupakan metode terbaik.

Tabel 4. Nilai Keakuratan Peramalan Data Testing

\begin{tabular}{crrr} 
Nilai Keakuratan & Single E.S & Double E.S & \multicolumn{1}{c}{ Triple E.S } \\
SSE & $164.794 .867,274$ & $71.686 .011,995$ & $82.403 .527,545$ \\
MSE & $7.490 .675,785$ & $3.258 .455,091$ & $3.745 .614,888$ \\
MAPE & 0,067 & 0,046 & 0,055 \\
\hline
\end{tabular}

Metode Double Eksponential Smoothing terpilih sebagai metode peramalan terbaik untuk data jumlah

\section{Peramalan Jumlah Penumpang Kereta Api Tahun 2018}

Tahapan terakhir adalah melakukan peramalan jumlah penumpang kereta api di Indonesia bulan Januari sampai dengan Desember 2018 dengan menggunakan metode penumpang kereta api karena ketiga nilai keakuratannya memiliki nilai terkecil diantara metode yang lainnya.

Double Eksponential Smoothing. Hasil peramalannya dalam ribuan dapat dilihat Tabel 5 di bawah ini.

Tabel 5. Peramalan Jumlah Penumpang Kereta Api di Indonesia Tahun 2018

\begin{tabular}{cccccc}
\hline Januari & Februari & Maret & April & Mei & Juni \\
31653,15 & 3176,15 & 31859,15 & 31962,15 & 32065,15 & 32168,15 \\
Juli & Agustus & September & Oktober & November & Desember \\
32271,15 & 32374,15 & 32477,15 & 32580,15 & 32682,15 & 32786,15 \\
\hline \hline
\end{tabular}

Tabel 5 di atas menunjukkan bahwa hasil peramalan Tahun 2018 menunjukkan bahwa data meningkat dari bulan ke bulan sepanjang tahun.

\section{PENUTUP}

\section{Simpulan}

Metode Double Eksponential Smoothing terpilih seba gai metode peramalan terbaik untuk data jumlah penump ang kereta api di Indonesia karena ketiga nilai keakuratan nya (SSE, MSE, dan MAPE) memiliki nilai terkecil diant ara metode yang lainnya. Kombinasi nilai $\alpha=0,645$; 
$\beta=0,154$ dan $\gamma=-$ memberikan nilai SSE terkecil diantara nya yaitu sebesar 157444122 , sehingga model persamaan Double Eksponential Smoothing adalah

$$
\begin{aligned}
& S_{t}=0,645 X_{t}+0,355\left(s_{t-1}+b_{t-1}\right) \\
& b_{t}=0,154\left(s_{t}+S_{t-1}\right)+0,846 b_{t-1}
\end{aligned}
$$

\section{DAFTAR PUSTAKA}

Aimran, A. N., \& Afthanorhan, A. (2014). A comparison between single exponential smoothing (SES), double exponential smoothing (DES), holts (brown) and adaptive response rate exponential smoothing (ARRES) techniques in forecasting Malaysia populationfff. Global Journal of Mathematical Analysis, 2(4), 276. https://doi.org/10.14419/gjma.v2i4.3253

Bermúdez, J. D., Segura, J. V., \& Vercher, E. (2007). Holt-Winters forecasting: An alternative formulation applied to UK air passenger data. Journal of Applied Statistics, 34(9), 1075-1090. https://doi.org/10.1080/02664760701592125

Ferbar Tratar, L., Mojškerc, B., \& Toman, A. (2016). Demand forecasting with four-parameter exponential smoothing. International Journal of Production Economics, 181, 162-173. https://doi.org/10.1016/j.ijpe.2016.08.004

Semuel, H., \& Wijaya, N. (2010). Service Quality, Perceived value, Satisfaction, Trust, dan Loyalty pada PT. Kereta Api Indonesia Menurut Penilaian Pelanggan Surabaya. Jurnal Manajemen Pemasaran, 4(1), 23-37. https://doi.org/10.9744/pemasaran.4.1.pp. 23-37
Hasil peramalan jumlah penumpang kereta api di Indonesia 2018 menunjukkan bahwa adanya peningkatan dari bulan ke bulan sepanjang tahun.

\section{Saran}

Peneliti selanjutnya dapat menggunakan metode ARIMA atau time series multivariat untuk melakukan peramalan. 